\title{
Pengaruh Pelatihan Konselor Sebaya pada Remaja Desa Purwobinangun Sleman Terhadap Pengetahuan dan Keterampilan Memberikan Konseling HIV / AIDS
}

\author{
Nisaatul Maharanita Fitrianingrum ${ }^{1}$, Supiyati ${ }^{2}$, Sumarni $^{3}$ \\ Kebidanan Sekolah Voaksi Universitas Gadjah Mada ${ }^{1}$ \\ Poltekes Kemenkes Yogyakarta ${ }^{2}$ \\ Fakultas Kedokteran Universitas Gadjah $\mathrm{Mada}^{3}$ \\ nisaatul.maharanita@mail.ugm.ac.id ${ }^{1}$, upik_bu@gmail.com², bu_sumarni@yahoo.co.id ${ }^{3}$
}

\begin{abstract}
ABSTRAK
Latar Belakang: HIV merupakan virus penyebab AIDS yang merusak sistem kekebalan tubuh manusia dan menjadi target Sustainable Development Goals (SDGs) untuk dieradikasi pada tahun 2030. Salah satu upaya yang dapat dilakukan adalah dengan kegiatan pemberdayaan masyarakat melalui pemberian pelatihan konselor sebaya tentang HIV/AIDS pada remaja desa.

Tujuan: Mengetahui pengaruh pelatihan konselor sebaya terhadap pengetahuan dan keterampilan remaja dalam memberikan konseling HIV / AIDS.

Metode: Penelitian ini merupakan penelitian quasy experimental dengan rancangan one group pre test and post test design. Subyek penelitian ini adalah remaja karang taruna di Desa Purwobinangun, Sleman sebanyak 38 orang. Penelitian dilaksanakan pada bulan November hingga Desember 2017. Pengumpulan data dilakukan secara cluster sampling dengan menggunakan kuesioner pengetahuan tentang HIV / AIDS dan observasi keterampilan konseling HIV / AIDS sebelum dan sesudah pelatihan. Analisis data dilakukan dengan menggunakan dependent $t$-test dan regresi linier ganda.

Hasil: Hasil penelitian menunjukkan bahwa terdapat perbedaan pengetahuan secara signifikan antara sebelum dan sesudah diberi pelatihan dengan $\mathrm{p}=0,000$; nilai $t$ hitung sebesar 8,72 dan terdapat perbedaan keterampilan secara signifikan sebelum dan sesudah diberi pelatihan dengan selisih ratarata $\mathrm{p}=0,000$; nilai $t$ hitung sebesar 13,79 . Hasil uji regresi linier ganda menunjukkan bahwa faktor luar berupa jenis kelamin, pendidikan, dan paparan informasi secara simultan memiliki pengaruh sebesar 9,5\% terhadap peningkatan pengetahuan dan 6,3\% terhadap peningkatan keterampilan remaja.

Kesimpulan: Terdapat perbedaan pengetahuan dan keterampilan remaja setelah diberikan pelatihan konselor sebaya tentang HIV / AIDS.
\end{abstract}

Kata kunci: HIV/AIDS, pelatihan konselor sebaya, remaja.

\begin{abstract}
Background: HIV is a virus that caused AIDS as destroyer of the human immune system which become the target of Sustainable Development Goals (SDGs) program to be eradicated in year 2030. An effort which is able to be done is holding a community empowerment activity through peer counselor training about HIV/AIDS to adolescent in village.

Objective: This research was aimed to know the effect of peer-counselor training for adolescent in Purwobinangun village, Sleman, about knowledge and skill in giving HIV/AIDS counseling.

Methods: It was a quasy-experimental research using one group pre-test and post-test design which followed by 38 member of youth organization (karang taruna) in Purwobinangun Village, Sleman. The data collection was conducted by using knowledge questionnaires about HIV/AIDS and skill observation form about HIV/AIDS counseling for pre-test and post-test from November to December 2017. The sample was conducted by cluster sampling method. The statistical method that used were dependent $t$-test and multiplied linear regression.

Results: The result of this research shown that there were differences among knowledge and counseling skill before and after being given the counseling training. The enhancement of knowledge's was $p=0,000 ; t=8,72$ and the enhancement of skill's was $p=0,000 ; t=13,79$. The result of multiplied linear regression analysis shown that other factors such as sex, education, and information sources simultaneously influeced 9,5\% to knowledge's enhancement and 6,3\% to skill's enhancement.

Conclusion: There were differences among adolescents' knowledge and counseling skill after being given a HIV/AIDS peer counselor training.
\end{abstract}

Keywords: Adolescent, HIV/AIDS, and peer counselor training. 


\section{PENDAHULUAN}

Pembangunan kesehatan adalah usaha yang dilakukan oleh seluruh elemen kehidupan dalam rangka peningkatan kesadaran, kemauan, dan kemampuan hidup sehat bagi setiap orang yang mana kontribusi produktif dalam pembangunan masyarakat dapat diberikan oleh individu yang sehat dan memiliki kemampuan fisik serta daya pikir yang lebih kuat. Kesinambungan antar upaya program dan sektor, serta kesinambungan dengan upaya-upaya yang telah dilaksanakan oleh periode sebelumnya menentukan keberhasilan pembangunan kesehatan. (Kemenkes RI, 2015).

Sustainable Development Goals (SDGs), sebagai kelanjutan dari program Millenium Development Goals (MDGs), merupakan tujuan global untuk mengakhiri kemiskinan, melindungi dunia, dan meyakinkan penduduk dunia untuk menikmati kedamaian dan kemakmuran. Pada bidang kesehatan, tujuan SDGs adalah terciptanya kondisi kesehatan masyarakat dunia yang baik dan sejahtera (UNDP, 2017). Salah satu agenda SDGs dalam pencapaian tujuan kesehatan yang spesifik adalah berakhirnya epidemi penyakit AIDS pada tahun 2030 (WHO, 2016).

HIV (Human Immunodeficiency Virus) merupakan virus penyebab AIDS (Acquired Immunodeficiency Syndrom). $\mathrm{HIV}$, retrovirus yang mengandung enzim, mengubah RNA menjadi salinan DNA dan kemudian masuk ke dalam susunan DNA pada sel manusia ketika telah terinfeksi ditularkan melalui kontak seksual, paparan darah, dan penularan melalui plasenta dari ibu ke janin, maupun menyusui. Infeksi HIV dapat menyebabkan kerusakan yang progresif pada sistem imun. Akibatnya, orang yang terinfeksi HIV rentan terhadap berbagai penyakit. Infeksi ini merupakan infeksi pandemis yang tidak dapat disembukan dengan segera bahkan dengan vaksin pencegah sekalipun (Gallant, 2008).

Masa remaja merupakan masa transisi dari kanak-kanak ke dewasa dimulai dari usia 10-13 tahun dan berakhir pada tahun 18-22 tahun yang meliputi perubahan biologis, perubahan psikologis, serta perubahan sosial (Notoadmodjo, 2011).

Pada tahun 2013 terdapat 35 juta orang hidup dengan HIV di seluruh dunia yang terdiri dari 3,2 juta anak berusia kurang dari 15 tahun. Sedangkan jumlah kematian akibat AIDS sebanyak 190.000 pada anak yang berusia kurang dari 15 tahun. Kasus HIV AIDS di Indonesia pertama kali ditemukan di provinsi Bali dan meluas di 386 kabupaten/kota di seluruh provinsi di Indonesia (Kemenkes, 2014). Di Kabupaten Sleman, Yogyakarta, merupakan provinsi dengan rawan bencana yang memiliki angka kejadian HIV / AIDS sebanyak 173 kasus pada tahun 2015 serta mengalami peningkatan setiap tahunnya (PKBI Jogja, 2015).

Hasil studi pendahuluan yang telah dilakukan pada bulan Mei 2017 adalah, bahwasannya masih terdapat angka kejadian HIV/AIDS sebanyak 12 orang sejak tahun 2012 di Desa Purwobinangun. Informasi ini diyakinkan oleh bidan bidang HIV / AIDS Puskesmas Pakem bahwa angka kejadian HIV / AIDS tersebut terjadi pada laki-laki berusia $25-45$ tahun dan seorang ibu hamil. Hal ini terjadi akibat pengetahuan masyarakat mengenai HIV/AIDS masih kurang sehingga dapat memberikan dampak terhadap peningkatan kejadian HIV/AIDS yang disebabkan oleh seks bebas yang dimulai dari usia remaja di desa tersebut. Meningkatnya kenakalan remaja, kehamilan di luar nikah, pernikahan usia dini, dan putus sekolah pada remaja sebagai risiko terjadinya HIV/AIDS di Desa Purwobinangun memerlukan penanganan yang tepat, segera, dan berkelanjutan.

Menurut Cahyono (2008), upaya penanggulangan HIV/AIDS yang dapat dilakukan pada remaja salah satunya adalah memberdayakan mereka dengan memberikan pelatihan konselor sebaya, yang diarahkan sebagai upaya pencegahan HIV pada remaja di Desa Purwobinangun.

Pencegahan

HIV / AIDS

merupakan bagian dari promosi kesehatan. Promosi kesehatan yang dilakukan melalui pemberian pendidikan kesehatan efektif dilakukan untuk 
menunda aktivitas seksual. Salah satu komponen program yang dapat digunakan sebagai pencegahan primer permasalahan remaja yang komplek adalah program konseling sebaya (Allender, 2014).

Orang dewasa memiliki permasalahan yang berbeda dengan para remaja. Remaja mungkin tidak dapat mendiskusikan topik permasalahan yang sensitif seperti pubertas dengan orang tua mereka. Bahkan, mereka tidak ingin orang tua mereka mengetahui permasalahan yang mereka hadapi mengenai kesehatan dengan alasan privasi. Sehingga, perlu adanya kegiatan yang melibatkan remaja untuk mendampingi sebayanya dalam pemberian informasi tentang HIV / AIDS (Nies, 2011).

Dengan demikian, perlu
dilakukan pengetahuan dan keterampilan oleh remaja sebagai konselor sebaya dalam memberikan informasi atau konseling tentang HIV/AIDS melalui pelatihan konselor sebaya. Dalam penelitian ini, materi pelatihan yang diberikan adalah pengertian, penyebab, tanda gejala, faktor risiko, cara penularan, dan pencegahan, serta pengobatan HIV/AIDS dengan rumusan masalah "Apakah terdapat pengaruh pelatihan konselor sebaya pada remaja di Desa Purwobinangun, Kecamatan Pakem, Kabupaten Sleman terhadap pengetahuan dan keterampilan memberikan konseling mengenai HIV / AIDS?"

Tujuan umum dari penelitian ini adalah untuk mengetahui pengaruh pelatihan konselor sebaya pada remaja desa terhadap peningkatan pengetahuan dan keterampilan remaja tentang HIV/AIDS di Desa Purbowinangun, Kecamatan Pakem, Kabupaten Sleman.

\section{METODE}

Penelitian quasy experimental ini dilakukan dengan rancangan one group pre test and post test design. Adapun subyek yang terlibat dalam penelitian ini adalah remaja karang taruna di Desa Purwobinangun, Sleman sebanyak 38 orang. Penelitian dilaksanakan pada bulan
November hingga Desember 2017. Pengumpulan data dilakukan secara cluster sampling dengan menggunakan kuesioner pengetahuan tentang HIV/AIDS dan observasi keterampilan konseling HIV/AIDS sebelum dan sesudah pelatihan.

Hasil pre-test dan post-test diasumsikan bahwa peningkatan pengetahuan dan keterampilan remaja tentang HIV/AIDS merupakan efek dari pelatihan yang diberikan. Dependent t-test dan regresi linier ganda dipilih sebagai teknik analisis data dalam penelitian ini.

Modul yang digunakan dalam pelatihan konselor sebaya ini diadopsi dari modul pelatihan konseling kesehatan reproduksi remaja bagi calon konselor sebaya dan dicetak untuk membekali kader remaja agar dapat melakukan konseling kepada teman sebaya BKKBN (2008).

\section{HASIL DAN PEMBAHASAN \\ HASIL}

Analisis Univariat

Analisis univariat dilakukan dengan tujuan untuk mengetahui gambaran tingkat pengetahuan dan keterampilan subyek penelitian.

Pengetahuan remaja sebelum dan sesudah pelatihan konselor sebaya

Tabel 4.2 Analisis pre-test dan post-test pengetahuan remaja

\begin{tabular}{lcccc}
\hline \multicolumn{1}{c}{ Variabel } & Mean & Median & $\begin{array}{c}\text { Nilai } \\
\text { Min. }\end{array}$ & $\begin{array}{r}\text { Nilai } \\
\text { Maks. }\end{array}$ \\
\hline $\begin{array}{l}\text { Pengetahuan } \\
\text { Pre test }\end{array}$ & 25,97 & 27,00 & 17 & 35 \\
Post test & 30,61 & 30,50 & 24 & 38 \\
\hline
\end{tabular}

Sumber: Data primer 2017

Pengetahuan remaja berdasarkan hasil pre test dan post test dengan jumlah sampel 38 orang menunjukkan rata-rata nilai pre testadalah 25,97 dan rata-rata nilai post test adalah 30,61. Sebelum diberi pelatihan, skor minimal pre test pengetahuan sebesar 17. Setelah diberi pelatihan, skor minimal pengetahuan remaja mengalami peningkatan hingga 24 . 
Keterampilan remaja sebelum dan sesudah pelatihan konselor sebaya

Tabel 4.3 Analisis pre-test dan post-test keterampilan remaja

\begin{tabular}{lcccc}
\hline \multicolumn{1}{c}{ Variabel } & Mean & Median & $\begin{array}{c}\text { Nilai } \\
\text { Min. }\end{array}$ & $\begin{array}{c}\text { Nilai } \\
\text { Maks. }\end{array}$ \\
\hline $\begin{array}{l}\text { Keterampilan } \\
\text { Pre test }\end{array}$ & 16,47 & 17,00 & 10 & 22 \\
Post test & 24,11 & 24,00 & 14 & 29 \\
\hline
\end{tabular}

Sumber: Data primer 2017

Keterampilan remaja berdasarkan hasil pre test dan post test dengan jumlah sampel 38 orang menunjukkan rata-rata nilai pre testadalah 16,47 dan rata-rata nilai post test adalah 24,11. Sebelum diberi pelatihan, skor minimal pre test keterampilan sebesar 10. Setelah diberi pelatihan, skor minimal keterampilan remaja mengalami peningkatan hingga 14 .

\section{Analisis Bivariat}

Analisis bivariat bertujuan untuk melihat hubungan antara variabel bebas dan variabel terikat. Variabel bebas dalam penelitian ini adalah pengetahuan HIV/AIDS dan keterampilan konseling HIV / AIDS. Setelah diketahui bahwa datadata yang dianalisis terdistribusi normal, uji statistika yang digunakan pada analisis bivariat adalah dependent t-test. Uji statistika ini bertujuan untuk menganalisis perbedaan skor pengetahuan dan keterampilan sebelum diberikan pelatihan dan sesudah diberikan pelatihan. Rentang skor yang digunakan pada variabel pengetahuan adalah 0 sampai dengan 40 dan pada variabel keterampilan adalah 0 sampai 30. Tingkat kemaknaan $p<0,05$ digunakan sebagai tolok ukur perbedaan variabel yang diukur.

Perbedaan pengetahuan remaja sebelum dan sesudah pelatihan konselor sebaya

Tabel 4.4 Analisis perbedaan pengetahuan sebelum dan sesudah pelatihan

\begin{tabular}{lcccc}
\hline Variabel & Mean & t-hit & CI 95\% & $\boldsymbol{P}$ \\
\hline Pre test & 25,97 & 8,72 & $3,56-5,71$ & 0,000 \\
Post test & 30,61 & & & \\
Selisih & 4,6 & & & \\
rerata & & & & \\
\hline
\end{tabular}

Sumber: Data primer 2017

Tabel di atas menunjukkan bahwa terdapat peningkatan antara pre test dan post test skor pengetahuan sebesar 4,6 .
Analisis yang dilakukan dengan menggunakan uji dependent t-test diperoleh nilai $\mathrm{p}=0,000(\mathrm{p}<0,05)$ dengan nilai $t$ hitung sebesar 8,72 (lebih dari $t$ tabel; 2,02 ). Hal ini berarti bahwa, secara statistik terdapat perbedaan yang signifikan antara pelatihan konselor sebaya terhadap pengetahuan remaja sebelum dan sesudah pelatihan.

Perbedaan keterampilan remaja sebelum dan sesudah pelatihan konselor sebaya

Tabel 4.5 Analisis perbedaan keterampilan sebelum dan sesudah pelatihan

\begin{tabular}{lcccc}
\hline Variabel & Mean & t-hit & CI 95\% & $p$ \\
\hline Pre test & 16,47 & 13,79 & $6,51-8,75$ & 0,000 \\
Post test & 24,11 & & & \\
Selisih & 7,63 & & & \\
rerata & & & & \\
\hline
\end{tabular}

Sumber: Data primer 2017

Tabel di atas menunjukkan bahwa terdapat peningkatan antara pre test dan post test skor keterampilan sebesar 7,63. Analisis dilakukan dengan menggunakan uji dependent t-test diperoleh nilai $\mathrm{p}=$ $0,000(\mathrm{p}<0,05)$ dengan nilai $t$ hitung sebesar 13,79 (lebih dari $t$ tabel; 2,02). Hal ini berarti bahwa secara statistik terdapat perbedaan secara signifikan antara pelatihan konselor sebaya terhadap keterampilan remaja sebelum dan sesudah pelatihan.

\section{Analisis Multivariat}

Dalam penelitian ini, analisis multivariat ditujukan untuk melihat hubungan antara variabel luar dan variabel terikat dengan mengontrol variabel luar. Variabel terikat pada penelitian ini adalah pengetahuan dan keterampilan, sedangkan variabel luar berupa jenis kelamin, pendidikan, dan paparan informasi. Pada tabel 4.6 dan 4.7 di bawah ini diperlihatkan hubungan variabel luar seperti jenis kelamin, pendidikan, dan paparan informasi dengan pengetahuan serta keterampilan subyek penelitian sebelum dan sesudah pelatihan. Dalam penelitian ini, analisis multivariat dilakukan dengan menggunakan analisis regresi linear berganda. 


\begin{tabular}{|c|c|c|c|c|}
\hline $\begin{array}{l}\text { Pengaruh } \\
\text { pengetahuar } \\
\text { Tabel 4.6. }\end{array}$ & $\begin{array}{l}\text { variabel } \\
\text { remaja } \\
\text { nalisis variak } \\
\text { engetahuan } 1\end{array}$ & $\begin{array}{l}\text { luar } \\
\text { maja }\end{array}$ & terh & dap \\
\hline Variabel & CI 95\% & $p$ & t-hit & $R^{2}$ \\
\hline $\begin{array}{l}\text { Jenis } \\
\text { kelamin }\end{array}$ & $-4,75-2,81$ & 0,60 & $-0,52$ & 0,095 \\
\hline $\begin{array}{l}\text { Jenjang } \\
\text { pendidikan }\end{array}$ & $-5,85-1,84$ & 0,30 & $-1,06$ & \\
\hline $\begin{array}{l}\text { Paparan } \\
\text { Informasi }\end{array}$ & $-4,23-0,31$ & 0,09 & $-1,75$ & \\
\hline
\end{tabular}

Sumber: Data primer, 2017

Pada tabel 4.6 signifikasi variabel jenis kelamin $(0,60)$, jenjang pendidikan $(0,30)$, dan paparan informasi $(0,09)$ dengan tingkat kepercayaan $95 \%$ adalah lebih dari 0,05 . Hal ini berarti, masing-masing variabel luar tersebut tidak memberikan pengaruh yang signifikan terhadap pengetahuan subyek penelitian sebelum dan sesudah pelatihan. Nilai $R^{2}$ pada ketiga variabel luar tersebut sebesar 0,095 yang berarti bahwa variabel jenis kelamin, jenjang pendidikan, dan paparan informasi memberikan pengaruh sebesar $9,5 \%$ secara simultan terhadap perbedaan pengetahuan subyek penelitian sebelum dan sesudah pelatihan.

\begin{tabular}{|c|c|c|c|c|}
\hline $\begin{array}{l}\text { Pengaruh } \\
\text { keterampilar } \\
\text { Tabel } 4.7 \\
\end{array}$ & $\begin{array}{l}\text { variabel } \\
\text { remaja } \\
\text { alisis variab } \\
\text { terampilan r }\end{array}$ & $\begin{array}{l}\text { luar } \\
\text { maja }\end{array}$ & terha & lap \\
\hline Variabel & CI 95\% & $p$ & t-hit & $\mathbf{R}^{2}$ \\
\hline $\begin{array}{l}\text { Jenis } \\
\text { kelamin }\end{array}$ & $-2,63-5,39$ & 0,49 & $-0,70$ & 0,063 \\
\hline $\begin{array}{l}\text { Jenjang } \\
\text { pendidikan }\end{array}$ & $-1,12-7,04$ & 0,15 & $-1,48$ & \\
\hline $\begin{array}{l}\text { Paparan } \\
\text { Informasi }\end{array}$ & $-1,72-3,09$ & 0,57 & $-0,58$ & \\
\hline
\end{tabular}

Sumber: Data primer, 2017

Pada tabel 4.7 signifikasi variabel jenis kelamin $(0,49)$, jenjang pendidikan $(0,15)$, dan paparan informasi $(0,57)$ dengan tingkat kepercayaan $95 \%$ adalah lebih dari 0,05 . Hal ini berarti, masing-masing variabel luar tersebut tidak memberikan pengaruh yang signifikan terhadap keterampilan subyek penelitian sebelum dan sesudah pelatihan. Nilai $\mathrm{R}^{2}$ pada ketiga variabel luar tersebut sebesar 0,063 yang berarti bahwa variabel jenis kelamin, jenjang pendidikan, dan paparan informasi secara simultan memberikan pengaruh sebesar 6,3 \% terhadap perbedaan keterampilan subyek penelitian sebelum dan sesudah pelatihan.

\section{PEMBAHASAN}

\section{Karakteristik Subyek Penelitian}

Menurut Bloom (1964) cit. Zulfitri

(2016), pengetahuan berarti ingatan mengenai sesuatu yang diketahui melalui pengalaman belajar atau informasi dari orang lain dan keterampilan (skill) merupakan kemampuan untuk mengaplikasikan pengetahuan yang telah didapat ke dalam praktik dengan tujuan tertentu. Hal ini berarti bahwa pengetahuan dan keterampilan merupakan sesuatu yang didapat dari informasi (Suprapto, 2009).

Berdasarkan tabel 4.1, karakteristik subyek penelitian yang dipaparkan adalah jenis kelamin, pendidikan, dan paparan informasi. Menurut Simons-Morton (2012), informasi dan sikap mempengaruhi keterampilan. Informasi yang dimaksud adalah pelaksanaan pelatihan. Sedangkan sikap terbentuk melalui faktor predisposisi berupa faktor sosio-demografi usia dan jenis kelamin, serta faktor pendukung berupa sumber informasi (Maulana, 2007). Disamping itu, tingkat pendidikan yang ditempuh oleh remaja adalah minimal SMA dan perguruan tinggi. Hal ini didasarkan pada teori Azam (2016) yang menyatakan bahwa sebagai seorang konselor, setidaknya diutamakan memiliki pendidikan minimal setingkat SMA.

Subyek penelitian yang mengikuti pelatihan tersebut diberikan intervensi sebanyak dua kali pertemuan setelah pelaksanaan pre-test. Kemudian, pengetahuan dan keterampilan mereka setelah pelatihan diukur sebagai bentuk evaluasi dengan pemberian post-test. Kondisi ini sesuai dengan teori Kirkpatrick (2007) yang menyatakan bahwa setelah pelatihan perlu diadakan evaluasi untuk mengetahui efektivitas program pelatihan yang telah dilaksanakan dengan cara mengevaluasi pengetahuan, sikap, dan keterampilan pra dan pasca pelaksanaan program. 


\section{Perbedaan pengetahuan sebelum dan sesudah pelatihan konselor sebaya}

Hasil analisis data pada tabel 4.4 adalah terdapat perbedaan yang bermakna pada skor pengetahuan sebelum dan setelah intervensi. Peningkatan skor pengetahuan sebesar 4,4 poin menunjukkan bahwa terdapat perbedaan skor rerata pengetahuan sebelum dan sesudah diberi pelatihan berupa peningkatan skor pengetahuan subyek penelitian. Hal ini sesuai dengan penelitian yang dilakukan oleh Triyanto (2013) yang menyatakan bahwa pelatihan konselor sebaya dapat meningkatkan pengetahuan sebanyak $80 \%$ berdasarkan hasil pre test dan post test. Penelitian lain dari Mevsim, dkk. (2008) menyatakan bahwa pelatihan konselor sebaya mampu meningkatkan pengetahuan selama sesi pelatihan sebesar $21,6 \%$.

Keberhasilan peningkatan pengetahuan ini didukung oleh teori Piaget cit. Suparno (2012) yang menyatakan bahwa unsur pendidikan yang berupa pengalaman dan pelatihan mempunyai pengaruh yang kuat terhadap pengetahuan seseorang. Pengetahuan tersebut diperoleh dan dibentuk oleh murid dan difasilitasi oleh guru atau fasilitator dengan menciptakan suasana agar proses pengetahuan tersebut terbentuk. Hal ini juga didukung dengan keberadaan kurikulum berupa penyusunan bahan ajar serta metode pendidikan yang sesuai dengan karakter peserta didik.

Dalam penelitian ini, peningkatan pengetahuan diasumsikan berasal dari pemberian pelatihan yang didasari kemauan peserta didik untuk terlibat aktif dalam kegiatan pelatihan, fasilitator ahli dalam bidang pelatihan konselor sebaya yang mampu menciptakan suasana pelatihan menjadi menyenangkan sehingga informasi dapat disampaikan dengan baik, kurikulum dan bahan ajar yang diberikan sesuai dengan topik materi, dan metode pembelajaran dapat diterima sesuai dengan karakter remaja desa.
Perbedaan keterampilan sebelum dan sesudah pelatihan konselor sebaya

Uji dependent t-test pada tabel 4.5 menunjukkan rata-rata peningkatan keterampilan subyek penelitian sebesar 8,63 poin. Analisis tersebut berarti bahwa terdapat perbedaan skor rerata keterampilan sebelum dan sesudah diberi pelatihan berupa peningkatan skor keterampilan subyek penelitian dalam memberikan konseling tentang HIV / AIDS. Hasil yang tak berbeda didapat dari studi yang dilaksanakan oleh Harini (2014) yaitu peningkatan keterampilan (post test) mahasiswa pengurus PIK-KRM sebesar 19,1\% dipengaruhi secara bermakna oleh pelaksanaan program pelatihan konselor sebaya. Dalam hal ini, metode yang digunakan pada penelitian ini sudah sesuai dengan teori yang direkomendasikan.

Keberhasilan peningkatan keterampilan dalam penelitian ini didukung oleh teori Simons-Morton (1995) yang menyatakan bahwa tujuan dari pelaksanaan pelatihan adalah adanya peningkatan keterampilan mengenai topik pelatihan dari para peserta pelatihan dan pelatihan membuka kesempatan untuk menggali informasi, ide, metode, maupun keterampilan yang telah didapat saat pelatihan.

Berdasarkan hasil analisis pada variabel pengetahuan dan keterampilan di atas, menunjukkan bahwa terdapat perbedaan pengetahuan dan keterampilan remaja sebelum dan sesudah diberikan pelatihan konselor sebaya. Perbedaan tersebut berupa peningkatan pengetahuan dan keterampilan remaja dalam memberikan konseling HIV / AIDS. Hal ini sesuai dengan pendapat Rozalena (2016) yang menyatakan bahwasannya program pelatihan merupakan solusi terbaik untuk mengembangkan kemampuan seseorang selama prinsip-prinsip pelatihan dilakukan, seperti partisipasi aktif dari pelatih maupun peserta, peserta mampu mengaplikasikan ilmu yang telah didapat setelah pelatihan berakhir, dan adanya konsistensi pelatihan dengan materi pelatihan yang diberikan dapat memberikan umpan balik positif bagi peserta maupun pelaksana. Penelitian ini tidak sesuai dengan riset yang pernah 
dilangsungkan oleh Michielsen (2012) yang menyatakan bahwa pendidikan konselor sebaya tidak berhasil untuk mencapai tujuan utamanya, yaitu mengurangi kebiasaan perilaku berisiko dan hanya meningkatkan sedikit pengetahuan subyek penelitian.

Asumsi peningkatan pengetahuan dan keterampilan ini disebabkan karena sasaran pelatihan berupa remaja yang secara sukarela bersedia untuk diberi pelatihan dan dari fasilitator yang berpengalaman dalam memberikan pelatihan. Pemberian pelatihan disertai dengan sarana dan prasarana yang mendukung, seperti alat peraga dan modul pelatihan yang sesuai dengan topik pelatihan. Hal ini didukung oleh pendapat As'ad (1995) cit. Zulfitri (2016) yang menyatakan bahwa keberhasilan pelatihan tergantung pada sasaran pelatihan yang jelas, pelatih yang cakap, bahan-bahan pelatihan yang disusun berdasarkan sasaran pelatihan, metode-metode latihan beserta alat bantu yang digunakan, dan peserta latihan.

Pengaruh variabel luar terhadap tingkat pengetahuan dan keterampilan remaja dalam memberikan konseling HIV/AIDS

Pada hasil analisis variabel luar jenis kelamin membuktikan bahwa jenis kelamin tidak memberikan efek secara signifikan terhadap perbedaan pengetahuan dan keterampilan subyek penelitian pra dan pasca kegiatan pelatihan. Hal ini serupa dengan hasil studi Arfan (2009) yang menyatakan bahwa variabel jenis kelamin tidak memberikan pengaruh secara signifikan pada peningkatan pengetahuan dan keterampilan subyek penelitian mengenai kesehatan reproduksi remaja.

Hasil analisis untuk variabel pendidikan mengindikasikan bahwa tidak terdapat hubungan yang berarti antara pendidikan dengan perbedaan pengetahuan dan keterampilan subyek penelitian sebelum dan sesudah diberikan pelatihan. Hal ini sesuai dengan riset yang telah dilakukan oleh Zulfitri (2016) bahwa tidak ada hubungan yang bermakna antara pendidikan orang tua dengan peningkatan pengetahuan dan keterampilan subyek penelitian.

Paparan informasi yang bersumber dari media massa maupun non media massa tidak memberikan pengaruh terhadap perbedaan pengetahuan maupun keterampilan subyek penelitian sebelum dan sesudah pelatihan yang ditunjukkan dari nilai signifikansi lebih besar dari 0,05. Penelitian ini selaras dengan penelitian yang dilakukan oleh Benita (2012) untuk mengontrol variabel perancu yang menunjukkan bahwa paparan informasi tidak berpengaruh secara signifikan terhadap peningkatan pengetahuan dan keterampilan remaja sebelum dan sesudah pemberian pelatihan konselor sebaya. Penelitian ini tidak sesuai dengan pendapat Harini (2014) yang menyatakan bahwa paparan informasi dapat meningkatkan keterampilan subyek penelitian karena sebelumnya subyek penelitian telah mendapatkan stimulus yang bersumber dari paparan informasi dan diperkuat oleh informasi dari pelatihan dan modul pelatihan.

Pendidikan kesehatan tentang HIV/AIDS yang berbasis pemberdayaan pada remaja melalui pelatihan konselor sebaya untuk menambah pengetahuan dan keterampilan pada remaja perlu terus diterapkan pada remaja anggota karang taruna di tingkat desa. Pembelajaran ini sangat penting sebagai bentuk preventif untuk mengatasi masalah tingginya angka kejadian HIV/AIDS sejak dini. Pelatihan merupakan segmen dari pendidikan kesehatan yang melibatkan proses belajar untuk meningkatkan pengetahuan dan keterampilan di luar sistem pendidikan formal dalam jangka waktu yang relatif singkat berbasis praktik.

Keterbatasan penelitian ini adalah dari 16 padukuhan yang berada di Desa Purwobinangun, hanya tiga padukuhan yang bersedia diberikan intervensi sehingga tidak terdapat perwakilan konselor sebaya di masing-masing padukuhan.

Sedangkan kelemahan dari penelitian ini adalah intervensi yang diberikan pada subyek penelitian di masing-masing padukuhan dilakukan dalam waktu yang berbeda dikarenakan 
perbedaan kesediaan waktu antar padukuhan dan setelah selesai pelatihan hingga waktu posttest, peneliti tidak dapat mengontrol subyek penelitian yang melakukan praktik mandiri pemberian konseling pada teman sebayanya.

\section{PENUTUP}

Kesimpulan penelitian ini adalah bahwa pelatihan konselor sebaya mengenai HIV/AIDS berpengaruh secara signifikan terhadap peningkatan pengetahuan dan keterampilan remaja sebelum dan sesudah pelatihan.

Berdasarkan hasil, pembahasan, dan kesimpulan mengenai pengaruh pelatihan konselor sebaya terhadap peningkatan pengetahuan dan keterampilan remaja desa, rekomendasi yang dapat diberikan sebagai bahan pertimbangan adalah pelaksanaan pelatihan konselor sebaya perlu dikembangkan di lokasi lain dengan analisis yang lebih mendalam, penambahan jumlah variabel, dan jumlah sampel yang lebih besar, serta cakupan wilayah yang lebih luas disertai dengan dukungan penuh dari instansi pemerintahan, pendidikan, maupun kesehatan setempat.

\section{Ucapan Terima Kasih}

Ucapan terima kasih diberikan kepada kedua orang tua, Bapak Rakidi dan Ibu Ganewati, saudara kandung maupun ipar yang telah memberikan dukungan bagi penulis, serta teman-teman D4 Kebidanan SV UGM yang bersedia membantu proses pengambilan data saat penelitian.

\section{DAFTAR PUSTAKA}

Allender, J. E. al. (2014). Community \& Public Health Nursing: Promoting the Public's Health. Wolters Kluwer Health. China.

Arfan, M., Wilopo, S.A., Wahyuni, B. (2010). Efektivitas Pendidikan Kesehatan Melalui E-file Multimedia Materi KRR dan Tatap Muka di Kelas Terhadap Peningkatan Pengetahuan Kesehatan Reproduksi Remaja. Berita Kedokteran Masyarakat, 26(3).

Azam, U. (2016). Bimbingan dan Konseling
Perkembangan di Sekolah (Teori dan Praktik). Yogyakarta: Penerbit Deepublish.

Benita, N. R. (2012). Pengaruh Penyuluhan Terhadap Tingkat Pengetahuan Kesehatan Reproduksi Pada Remaja Siswa SMP Kristen Gergaji. Skripsi Universitas Diponegoro.

Cahyono, J. B. S. B. (2008). Gaya Hidup dan Penyakit Modern. Yogyakarta: Penerbit Kanisius.

Gallant, J. (2008). 100 Questions \& Answers about HIV and AIDS. Massachusetts: Jones Bartlett Publishers.

Harini, R. (2014). Upaya Peningkatan Keterampilan Konseling Kesehatan Reproduksi Mahasiswa Melalui Pelatihan Konselor Sebaya. Jurnal Ners, 9(2), 173-182.

Jogja, P. (2015). Angka Kejadian HIV/AIDS.

Kemenkes RI. (2015). Rencana Strategis Kementerian Kesehatan Tahun 20152019: Keputusan Menteri Kesehatan Republik Indonesia Nomor HK.02.02/MENKES/52/2015.

Jakarta: Kementerian Kesehatan RI.

Kirkpatrick, D. L. (2007). The Four Levels of Evaluation. Amerika: American Society For Training and Development Press.

Maulana, H. D. . (2007). Promosi Kesehatan. Penerbit Buku Kedokteran EGC. Jakarta.

Mevsim, V. E. al. (2008). What was retained? The assessment of the training for the peer trainers' course on short and long term basis. BMC Public Health 2008, 8(24).

Michielsen, K. E. al. (2012). Effectiveness of a peer-led HIV prevention intervention in secondary schools in Rwanda: results from a nonrandomized controlled trial. $B M C$ Public Health, 12(1), 729.

Nies, Mary A., McEwen, M. (2011). Community/Public Health Nursing: Promoting the Health of Population. United States of America: Elsevier Saunders.

Notoatmodjo, S. (2011). Kesehatan Masyarakat Ilmu dan Seni Edisi Revisi. Jakarta: Penerbit PT Rineka Cipta. 
Rozalena, et al. (2016). Panduan Praktis Menyusun Pengembangan Karier dan Pelatihan Karyawan. Jakarta: Penerbit Raih Asa Sukses.

Simons-Morton, Bruce G., et al. (1995). Introduction to Health Education and Health Promotion Second Edition. USA: Waveland Press, Inc.

Simons-Morton, Bruce G., et al. (2012). Behavior Theory in Health Promotion Practice and Research. USA: Library of Congress Cataloging-in Publication Data.

Suparno, P. (2012). Teori Perkembangan Kognitif Jean Piaget. Yogyakarta: Penerbit Kanisius.

Suprapto, T. (2009). Pengantar Teori dan Manajemen Komunikasi. Yogyakarta: Medpress.

Triyanto, E., Rahayu, E., dan Puspita, D. R. (2013). Pengembangan Pusat Konseling Mahasiswa Unsoed
Melalui Pendidikan dan Pelatihan Mahasiswa sebagai Peer Counselor. Jurnal Keperawatan Soedirman, 8(3), 127-142.

UNDP. (2017). Sustainable Development Goals. Retrieved from http://www.undp.org/content/und $\mathrm{p} / \mathrm{en} / \mathrm{home} /$ sustainabledevelopment-goals.html

WHO. (2016). World Health Organization. Retrieved from http://www.who.int/mediacentre/f actsheets/fs345/en/

Zulfitri, R. (2016). Pengaruh Pelatihan Konselor Sebaya pada Siswa SMK terhadap Pengetahuan dan Keterampilan Memberikan Informasi Kesehatan Reproduksi Remaja. Yogyakarta: Fakultas Kedokteran Universitas Gadjah Mada. 